\title{
GOOD THOUGHTS IN BAD TIMES
}

\author{
A SERMON by HENRY CHURCHILL KING, D.D., LL.D., S.T.D. \\ President of Oberlin College, Oberlin, Ohio
}

Matt. 13:52: And he said unto them, Therefore every scribe who hath been made a disciple to the kingdom of heaven is like unto a man that is a householder, who bringeth forth out of his treasure things new and old.

Thomas Fuller's quaint old book, written in 1645 , in the midst of the critical days of England's Civil War, has given me my subject: "Good Thoughts in Bad Times." My text is Christ's conclusion from the great parables of the Kingdom, spoken at a crisis in his own ministry: "Every scribe who hath been made a disciple to the kingdom of heaven is like unto a man that is a householder, who bringeth forth out of his treasure things new and old" (Matt. 13:52). Jesus seems to have immediately here in mind those great truths-" the secrets of the Kingdom"which he had been bringing forth in the parables.

Now there is clear evidence in Matthew, and still more in Mark, that the use of parables marked a definite stage in the ministry of Jesus. A number of general preaching tours had preceded, ending in deeply disheartening comparative failure. For the barren Judean field, the doubt of John the Baptist, the refusal of Galilee to respond to his preaching, the bitter and growing opposition of the Pharisees, and even the misunderstanding of his kindred, all indicate that there was not to be a general receptiveness to his message.
What does this general refusal to hear the truth mean? How is he to bear it? How is he to meet the challenge of these evil times? In point of fact, the continually narrowing field of his work drives him to his deeper ministry to the little circle of the disciples and to the use of parables. And the way Jesus here took in a great crisis in his own ministry has deep-going suggestions for us too, as we think of the message of the minister of Christ in these crisis days. For both his changed method of teaching in the use of parables, and the great truths set forth in these parables of the Kingdom haveprofound lessons for us.

I. The lessons of the parabolic method. -And first, what are the lessons of his changed method? What insights and motives underlie his use of parables?

We may be certain, to begin with, that the changed method does not mean any lessened desire on Christ's part to win all men into the Father's love. His whole teaching and ministry forbid the thought. If he now, under force of circumstances, is concentrating his teaching upon a small inner group, it is still for the sake of all-to insure that the foundations of the new spiritual Kingdom shall be made secure through his persistent close association with a chosen few. These few are chosen for these weeks of intensive training in Christ's very presence in order that the "good news of God" may the more surely and the more truly come to all men. 
We may be equally certain that the changed method does not mean that there had been no place for such teaching as had preceded, like the Sermon on the Mount. Even the parables could not replace that. The method of wide public preaching must precede in order to give to all opportunity to hear the truth, to disclose thus all those kindred spirits who were drawn to it, and so to secure a self-selected group with whom the teaching might go farther, and who should become the solid nucleus of the new Kingdom.

Moreover it was imperative that there should be-as against the whole trend of the times-just such clear and explicit setting forth of the radically spiritual nature of the Kingdom of God, with its inevitable inner conditions of insight and ethical choice. Jesus' message must be decisively and unmistakably discriminated from that of the religious leaders of his day, or it will be swamped from the beginning.

But just because it is a radically spiritual Kingdom which Christ has come to found, calling for deep inner conditions on the part of those who will come into it, his message cannot be hastily and shallowly taken $u p$. It requires time and thought and attention. And the method of the parabolic teaching is exactly calculated to secure that result. Even the best-the little inner circlecould come into full appreciation of his message only gradually; and this the parables themselves express.

Now the use of parables helped to meet this situation, helped to keep the truth in men's minds until they could grow up to it. It kept their thought for a longer time upon the message,

noting the analogy and tracing it out. It kept them pondering the riddle of the parable. And the parable so gave, in this picture form, currency and permanence to the truth. Let one think in illustration, of the immense influence through generations of Bunyan's great parable, the Pilgrim's Progress.

At the same time, the parable form of the teaching saved those not yet prepared for the truth from hardening under its more direct and literal presentation. Indeed, for men in all stages of preparation the truth is hidden in the parable, not to remain hidden, but that it may be preserved for later use, for later revealing. As Jesus himself says in the germ parable of the lamp: "There is nothing hid, save that it should be manifested; neither was anything made secret, but that it should come to light. If any man hath ears to hear, let him hear" (Mark 4:22, 23).

The parable is especially adapted also to the nature of the teaching of Jesus. $\mathrm{He}$ is profoundly concerned to evoke from men a genuine inner life of their own-that they shall truly share in his own great insights and convictions and motives and ideals. He wishes none of these taken on in external fashion. He fights, therefore, as dangerous enemies of his Kingdom, rule-makers and rulekeepers. It particularly concerns him, thus, that his teaching shall be in such form as to reduce to the minimum this danger of its being turned into rules; and the parable is here a real safeguard.

But to establish an enduring spiritual kingdom among men is no holiday task. Jesus must have a tried and tested following, of men in earnest to find and to do the truth, of men who profoundly 
feel the appeal of his spirit, even where they have not yet fully comprehended his teaching. And the change to the method of the parable is particularly intended to secure such a sifting. The veiled teaching of the parable tests the earnestness of his hearers. Jesus is like a teacher who is aiming to secure a class made up of hard, dead-in-earnest workers. The parable is exactly adapted to bring the more earnest into closer relation to him, seeking him out, to follow up the partially disclosed truth. The use of parables, then, naturally acted like the opportunity for an inquiry meeting after preaching. Jesus' very method, thus, at this critical time in his ministry, is a sifting out of his following sifting out the dead in earnest, the spiritually minded, those akin to himself in spirit; sifting out the seed for the new world-harvest, getting the yeast of the great, new, world-leavening process. It is an indispensable, foundationmaking work.

At the same time the parables helped this sifted inner group to grasp the deeper significance of Jesus' teaching as nothing else could do. He is to make his great truths clear and real and powerful with his disciples. To do that, he must start where they are, with facts they know, with experiences they have had. $\mathrm{He}$ must knit the truth up with what is for them already undoubted reality. Therefore he makes it his habit to point out these convincing simple analogies of their common daily life. No wonder Mark says: "And with such parables and many of them, he was wont to speak to them the word, just as they were able to hear it" (Mark 4:33, Bartlett's translation).
All these reasons, then, may be said to lie back of the change by Jesus to the parabolic form of teaching at what may perhaps be called the most critical point in his ministry: because his teaching is of such a nature that it cannot be hastily and shallowly taken up, but requires time and thought and attention; because thus the parables helped to give both currency and permanence to his teaching; because they can be adapted to different stages of growth; because they do not lend themselves to a religion of rules; because they serve as a sifting process in securing the good seed of the Kingdom; and because they are the surest method of making the great truths of Christ's message - "the secrets of the Kingdom"-real and powerful with the selected inner group.

What does all this mean for the minister of Christ in these days of crisis? Every consideration here suggested concerns us now. For the laws of human nature, the laws of the Kingdom of the Spirit, have not changed. The more critical the danger, the more earnestly must spiritual law be obeyed. To abandon or lessen spiritual agencies now is folly unspeakable. Serious mistakes have been made at just this point in Europe in these years of war. The conditions for getting the truth home to the hearts and consciences of men are the same for the disciple of Christ today as for the Master himself then.

The insights and motives which led Christ to the method of parables we shall find expressed in the parables themselves, and need not reiterate here. But the method of the Master still remains imperative. To put the matter in a word, one whole side of the great 
business of the Christian ministry may be said simply to be clearly to discern, convincingly to state, the permeating likeness of the truth as it is in Christ to the realest things of the daily life with the conviction born of contact with undoubted reality - to be in some fashion always saying, "The Kingdom of Heaven is like." Whatever else happens to a man's spiritual ministry, every stitch of it must be real.

II. The lessons of the parables themselves.-When we turn to a thoughtful study of the parables themselves, it soon becomes clear that they are no chance stories or literary illustrations. They are interwoven with the warp and woof of the fabric of the experiences of Jesus at the time. The parables accurately reflect his consciousness at this period, and are spoken honestly and truly out of his own experience, as he faces the necessary obstacles of his own work. He is thinking aloud. The parable of the sower, for example, which both Matthew and Mark put first, is a kind of epitome of his whole ministry, with its record of comparative disheartening defeat. It explains why his message had so poor a response, and implies that he is now to concentrate upon the good soil-the earnest-minded who "hear the word and accept it."

The great truths which neither those in authority nor the multitudes were ready to receive (and which in part explain their unreceptiveness) he is now to make clear and powerful with his disciples through these simple analogies from their common daily life. With these truths-" "things new and old"he had cleared his own mind and girded his own soul. They constitute a kind of divine philosophy of life-" good thoughts in bad times." With them he now seeks to clear the thinking and gird the living, not only of the group immediately about him, but also of all his disciples in the years to come, for he looks with clear-eyed vision to the future.

We may well have especially in thought the parables which most surely belong to the beginning of this critical period, the parables of Mark, chap. 4, and Matt. chap. I3: the parables of the sower, of the tares, of the fruit-bearing earth, of the mustard seed, of the leaven, of the hidden treasure, and of the pearl of great price.

In all these parables it is evident that Christ's faith is no shallow faith, his optimism no shallow optimism, that comes from ignoring hard, dark facts. $\mathrm{He}$ is facing here-it seems almost sacrilegious to say it-the comparative failure of his ministry, his rejection by his own people. The world's supreme teacher, the supreme lover of men, God's supreme revelation, got from his own generation, not only an astoundingly small response, but bitter opposition, even unto death. That is a very black fact, the fact of dire human error and sin, and suggests that the religious teacher has to do with some stern realities that nothing can soften. And with these stern realities he must come to terms, if he is ever to understand his task or go courageously on with it.

These parables are Jesus' answer as to how he kept his faith in face of the appalling evidence of human sin. They may well command our thought, as we stand face to face with the most terrible exhibition of folly and sin which the world has seen since the crucifixion. 
In these parables Jesus calls to mind the solemn fact of human freedom (the sower, the tares); that there is a kingdom of evil to be recognized and its opposition to be expected (the sower, the tares); that evil is to be opposed positively by the good (tares, seed, leaven); the marvelous gradual growth of the good (seed, leaven, fruit-bearing earth); the infinite values at stake (hidden treasure, pearl of great price); and the final triumph of righteousness (seed, leaven, tares).

I. In the first place, Jesus is in dead earnest with the fact of human freedom. $\mathrm{He}$ knows that there can be no character, no really moral world, no true service of God, no genuine children of God, without freedom. God will be freely served. But Christ knows how fateful a fact freedom is. For it involves the whole dreadful possibility of human error and sin, that men can choose against the good of their fellows as well as with it, against God as well as with God.

Christ fully recognizes man as the decider of his own destiny; that the solemn issues of life depend upon both seed and soil, upon both the truth and the heart. Men must choose for themselves. The man who hears, himself determines the soil. Under the putting and the facing of the truth, therefore, a constant inevitable process of selection is going on, a sifting process. It holds for any audience. It holds for any situation in life. Truth, light, the best, is everywhere necessarily and continuously testing and sifting men out, for it is confronting them with a constant choice between a lower and a higher. Continually one is being weighed in the balances. We are not judging the truth so much as the truth is judging us. The real judgment of God is thus not so much an event as an eternal process. Man responds with consent or denial. It is therefore that Jesus says in the very midst of these parables: "If any man hath ears to hear, let him hear. Take heed what ye hear: with what measure ye mete it shall be measured unto you; and more shall be given unto you." That is, attention, heeding, sharing, are the essential conditions of growth. And these all rest with the man himself. Jesus solemnly warns, therefore, against all the enemies of growth: the convention and prejudice of the hardened path, the superficiality and the sentimentality of the shallow soil, and the deadening distraction of all lower interests. Whatever secures a man's attention secures him. Whatever continually distracts his attention from life's great issues is a dire enemy.

And all this is being demonstrated on a world-wide scale in these critical days. We are seeing anew how terrible a fact human freedom is. It is no mysterious, divine judgment which has come upon the world. Men have freely set before themselves certain dominating goals. In support of these freely chosen ends they are laying under tribute all the forces and resources of science and civilization in a great clash between irreconcilable ideals. The world has become so intimately and completely one that the results of men's and of nations' free choices tend to spread themselves over all the earth. We are thus getting a demonstration, wide as the race, that the final harvest of exclusive national selfishness freely chosen, of limitless arrogance freely cherished, of an 
anti-Christian philosophy of the state without one moral scruple, but freely taken on, is simply a hell on earth. The resulting situation is compelling the world, therefore, again freely to choose between national ideals, between ultimate goals of the race.

We have to reckon, as truly as Jesus ever reckoned, with the fateful fact of human freedom.

2. In this fact of human freedom another fact is involved, which Jesus illustrates in the parable of the sower and still more in the parable of the tares: There is a kingdom of evil to be recognized, and its opposition to be expected.

The victory of truth in a man's life is threatened, not only by his own wrong choices, but also by the evil choices of others. The very fact of a moral universe makes us members one of another, sharing in one another's lives for good and evil. An enemy may sow tares among the wheat. He is a foolish servant of righteousness who forgets this. The ingenious and fiendish devices by which wicked men seek their selfish profit by taking advantage of the hours of weakness and temptation of other men, in the saloon, in the omnipresence of gambling devices, in evil resorts, in demoralizing moving pictures, in the vice trust, daily illustrate this dark fact of the opposition of the evil. No servant of God has a right to ignore this evil sowing. $\mathrm{He}$ is to prevent it so far as he can. But much of it is involved in the very association of evil men. It cannot be simply rooted out except by changing the evil sowers themselves. Both wheat and tares must "grow together until the harvest."
How terrible may be this sowing of evil the world is seeing today as never before. The full meaning of much of the sowing was not seen at first. The evil was put forth in such plausible form as almost to seem good. Many were deceived. The tares looked like wheat. But millions of comparatively innocent men and women and children have been involved in the inevitable outworking of purposes now seen to be intrinsically evil, when strictly measured by the teaching of Christ. It is to be hoped that this will become unmistakably plain. For evil becomes more frightful in its results as the world becomes more unified.

The opposition of evil, then, is to be expected. It is a part of the meaning of our earthly life. The truth cannot take its course unopposed, and there must be determined courage, energetic persistence, unceasing vigilance, and an individually adaptable, long, longsuffering. Results earnestly sought by God and by his servants may be greatly marred by opposing evil. We are creatures of two worlds.

We are not then to be discouraged nor to give up our task because of opposition. That is to be counted on. There will always be objection and criticism and opposition even in the case of the best work. There was in Christ's case. One may know it beforehand and discount it accordingly, though in no unteachable spirit; and he is to go steadily on nevertheless in the work to which God calls him. Let him not be daunted by the specter of unpopularity. A cause or method or enterprise to which no one objects is too spineless to accomplish anything. 
There is, then, evil to be recognized and its opposition to be expected.

3. But it is to be further seen that Christ teaches (in the parables of the tares, the seed, the leaven, and the fruitbearing earth) that evil is to be conquered, not so much by negatively fighting evil, as by the positive growth of the good.

Jesus had no faith in the security of the empty soul, in the adequacy of a negative virtue. His conception of character is always the positive one of good will, of an active ministering love, of a genuine sharing in God's own life of endless self-giving. The only true victory over the evil will, therefore, is to replace it with positive good will. The completest protection against the tares is to have the ground fully occupied by the wheat. Only light can cast out darkness. No number of negative abstentions from evil can enthrone the good. Jesus seeks to give his disciples, therefore, a great new vision of good to be gained and accomplished, of great enthusiasms and causes to be taken on, of the glorious undertakings of the will of God. He is not trying to cut life short, to annihilate man's outreachings for larger life, man's tumultuous claims on life, but rather truly to satisfy them. He brings to men an emancipating message. $\mathrm{He}$ gives to men such a conception of God and such a conception of man as inevitably honeycombs and undermines ancient evils, though he seems not directly to attack them at all. He sets the captives free.

It is not always easy to follow this positive method of Jesus. We are prone to stop in destructive fighting. It seems a tame and prosaic process, this steady building up of the forces of good. It is accompanied by few revolutionary pyrotechnics. And yet it is the one great way for the triumph over evil in ourselves, in others, among the nations. And in these present evil days we need no reminder as much as this reminder of the eternal necessity of conquering evil by the growth of the good. No simple defeat of evildoers, no mere punishment of them, no limitations laid upon them, will at all suffice. There must be the victory of positive good will if a sure goal is to be reached.

4. But can we count upon the growth of the good? Is it not rather a very tender plant? Jesus girds his own soul and the souls of his disciples again (in the parables of the seed, leaven, fruit-bearing earth, and the tares) with his faith in the marvelous, gradual growth of the good from small beginnings and in the final triumph of righteousness. $\mathrm{He}$ could not believe in his Father and not have that faith. We are to share in his faith.

However small and unpromising the beginnings of good, he seems to say, you are surely to count, endlessly to count, on the co-operating power of God. Your daily life is witness. As surely as the minute seed grows miraculously into a plant a million times its own size; as surely as the little yeast permeates a great mass of meal until it is all leavened; as surely as "the earth beareth fruit of itself," and you have small share beyond the sowing of the seed-so surely you may count upon God's still greater co-operation in your efforts for the truth, for righteousness, for the establishment of his Kingdom. 
We greatly need to catch Christ's faith in the power of simple straightforward truth and character, not in great schemes, in wire-pulling, in machinery, in wealth. In Christ's thought it is the life which produces the organization, not the organization the life. Let his own case bear witness. What is indubitably the most effective moral force in the world? Christ's own life and teaching. But how infinitesimal the hope that it could be so, from a human standpoint! A Galilean peasant in a little unimportant Roman province, writing nothing, rejected by his own people, himself brought to the cross, dying young, having won only a handful of humble, unlettered followers! What promise is there that his ideals shall be, and come to be seen to be, the world's highest standards by which men and nations shall judge one another?

And let the constantly recurring missionary miracle bear witness. What folly it seems to put three or four common men and women, with the only message of Christian truth, into a great and populous and indifferent or hostile province, and expect any result! But the leaven works; the seed grows.

In our modern emphasis on evolution we are appealing to this same principle of growth. The believer in the Creator God must be sure that the world belongs to God and that his will is working out in it. In spite of delays and countercurrents, he believes with Fiske in the "omnipresent ethical trend" of the evolutionary process.

So Christ maintained an indomitable, calm, unshaken faith in the growth of the good from even the least beginnings -faith, that is, in God and in the spiritual forces. And ultimately this meant, it should be noticed, faith too in the response of men to higher appeals. One of the compensations which this terrible war is giving us is that we are getting a new faith in common men. It has revealed, not so much a few great men, as the heroic quality of multitudes of common men. As Mr. Wells puts it: "The acts of the small men in this war dwarf all the pretensions of the great man. . . . . When I was a young man I imitated Swift and posed for cynicism; I will confess that now at fifty and greatly helped by this war, I have fallen in love with mankind." It is as though God would bring us now to share in Christ's faith in men too as well as in God.

In the face, then, of feeble beginnings of good, and confronting great evils, when we seem only to be hiding away a little germ of life in the dark ground, or a little germ of yeast in a great mass of meal, all unleavened-and it seems a ridiculously small task and wholly inadequate-we are not to be discouraged. The seed will grow, the leaven will spread, and righteousness will triumph. If we work indeed for truth and for righteousness, we work in line with the ongoings of the eternal purpose of God. The good shall marvelously though gradually grow.

And Jesus sees not less clearly that the great goals of the Kingdom can be only gradually attained-"first the blade, then the ear, then the full grain in the ear." Great values cannot be made to order. Spiritual values require time to grow. "Faith is a deed." "Truth never becomes truth until it has been earned." The slowness with which spiritual values mature is no reason for 
unbelief or for discouragement. That slowness-like man's long and helpless infancy-is itself a pledge of greater significance and permanence. The workers for the Kingdom are building for eternity; they are not to be impatient of a little time. They are to lay deep foundations. Character is the most costly of all products - costly both to God and to men-just because it is the most precious.

In the parable of the tares Jesus expresses in another necessary way his faith in the final triumph of righteousness. Believing in human freedom, he knows that man cannot be forced even by God into righteousness. Jesus looks on, then, into another life, as the religious teacher must if he is to answer final questions; and he gives to his disciples the sorely needed assurance of a good God, that there is to be a great new epoch in the Kingdom of God; that the confusions and injustices and evil associations and machinations of this life are not to continue. "All things that cause stumbling" are to be gathered out, and the full meaning of the Kingdom of Righteousness to be revealed. "Then shall the righteous shine forth as the sun in the Kingdom of their Father."

5. The parables of the hidden treasure and of the pearl of great price are added to those of the seed and the leaven, as though to answer the sigh of the workers in the Kingdom: "But the progress is so slow, and the effort so great." In the parables of growth he has already in part suggested the answer, as we have seen. But here he says plainly: You must measure progress and effort by the value to be achieved. Infinite values are at stake.

The whole universe has gone to the making of man. That is the measure of man's cost and value. And it means that God counts no price too great to secure a household of true children. On the one hand, we cannot expect the greatest things to be appreciated at once. On the other hand, when we recognize the greatness of the goal which we seek, in character and Godlikeness for ourselves and others, a real Kingdom of God on earth, we need not wonder that it demands long stretches of time and endless pains. The highest possible values are not to be won easily and cheaply. With joy we pay all that we have.

In the presence of a torn and bleeding and desperately fighting world we catch a new vision of what Christ's goal would really mean for men-the Kingdom of Love, the civilization of men of the brotherly spirit. In a world in which the full fruits of selfishness and arrogance and falseness and turning one's back upon the standards of Christ have become manifest in suspicion and anxiety and terror and in an immeasurably impoverished life, one sees as never before how infinitely good would be Christ's Kingdom of Love, in which each shares in the best of each. No price is too great to pay for that goal. Even the superficial peace of years now gone, spread lightly over men's selfish aggressions, seems very sweet in retrospect. How much more a peace which should truly reflect the standards and ideals of Christ! God hasten its coming! 